\title{
Impact of Acquired Pellicle Modification on Adhesion of Early Colonizers
}

\author{
Zeinab Cheaib ${ }^{a}$ Ekaterina Rakmathulina ${ }^{a}$ Adrian Lussi $^{a}$ Sigrun Eick ${ }^{b}$ \\ Departments of a Preventive, Restorative and Pediatric Dentistry, and ${ }^{b}$ Periodontology, University of Bern, \\ Bern, Switzerland
}

\author{
Key Words \\ Bacterial adhesion · Casein · Dental erosion · Mucin · Oral \\ streptococci
}

\begin{abstract}
New preventive approaches against dental erosion caused by acidic drinks and beverages include fortification of beverages with natural polymers. We have shown that the mixture of casein and mucin significantly improved the erosion-inhibiting properties of the human pellicle layer. This study aimed to investigate the effect of pellicle modification by casein, mucin and a casein-mucin mixture on the adhesion of early bacterial colonizers. Test specimens of human tooth enamel were prepared, covered with saliva and coated with $0.5 \%$ aqueous (aq.) casein, $0.27 \%$ aq. mucin or with $0.5 \%$ aq. casein- $0.27 \%$ aq. mucin, after which the adhesion of Streptococcus gordonii, Streptococcus oralis, and Actinomyces odontolyticus was measured after incubation for $30 \mathrm{~min}$ and $2 \mathrm{~h}$. $\log _{10}$ colony-forming units were compared by nonparametric tests. All three bacterial strains adhered in higher number to pellicle-coated enamel than to native enamel. The protein modifications of pellicle all decreased the counts of adhering bacteria up to $0.34 \log _{10} / \mathrm{mm}^{2}$, the most efficient being the casein-mucin mixture. In addition to the recently shown erosion-reducing effect by casein-mucin, modification of the pellicle may inhibit bacterial adherence compared to untreated human pellicle.

(c) 2015 S. Karger AG, Basel
\end{abstract}

Caries is associated with bacterial processes leading to damage to the hard dental tissues (enamel, dentine and cementum) and remains one of the most common diseases worldwide [Kassebaum et al., 2015]. Caries results from the interplay of three main factors: dietary carbohydrates, cariogenic bacteria on the dental surface and susceptibility of hard tooth tissue to demineralization [Kutsch and Young, 2011; Bradshaw and Lynch, 2013].

The prevalence of dental erosion is steadily increasing in European countries and requires effective preventive solutions [Jaeggi and Lussi, 2014]. It is widely documented that acidic beverages as well as gastric juice may cause dental erosion [Lussi et al., 1995, 2012; Sovik et al., 2015; Wilder-Smith et al., 2015]. New approaches to prevent dental erosion, which include fortification of beverages with natural polymers or with dietary proteins such as ovalbumin from egg white, have been reported to reduce acid-induced hydroxyapatite dissolution [Barbour et al., 2008; White et al., 2011]. Furthermore, when added to commercial soft drinks or simple acidic solutions, casein subfractions ( $\alpha-, \beta-$ and $\kappa_{-}$) and ovalbumin reduced enamel erosion in the presence of the acquired pellicle [Hemingway et al., 2008]. The addition of dietary proteins to soft drinks is currently regarded as a promising preventive measure as it does not spoil the taste and carries no risk of dental staining. In our previous study, we proved that modification of salivary pellicle by casein and a casein-mucin mixture (mucin salivary protein) in-

\section{KARGER 125}

(C) 2015 S. Karger AG, Basel

0008-6568/15/0496-0626\$39.50/0

E-Mail karger@karger.com

www.karger.com/cre
Sigrun Eick

Department of Periodontology, University of Bern

Freiburgstrasse 7

$\mathrm{CH}-3010$ Bern (Switzerland)

E-Mail sigrun.eick@zmk.unibe.ch 
creased the ability of the pellicle layer to protect against erosive enamel demineralization [Cheaib and Lussi, 2011]. Interestingly, application of a casein-mucin mixture for pellicle modification showed greater anti-erosive efficacy than application of casein alone. In spite of the proven efficiency of these proteins in the inhibition of enamel demineralization and wear, it is not clear if incorporating them into the pellicle layer can also interfere with bacterial adhesion provoking or preventing caries. Thus, it is necessary to assess the preventive effect of proteins against dental erosion as well as against caries. Such complementary studies are much in demand in this field.

Bacterial colonization starts with the adhesion of early colonizers, known as pioneer bacteria, to the salivary pellicle of the teeth, as well as of the dental restoration, within minutes after tooth cleaning. These early colonizers, mostly streptococci and Actinomyces spp., contribute to plaque development and ultimately to oral diseases [Li et al., 2004]. The bacterial adhesion occurs via specific receptors located in the salivary pellicle layer and follows the typical stages of biofilm formation [Marsh, 2004].

The molecular composition and physicochemical properties of the pellicle are critical in determining the pattern of microbial colonization. As bacteria approach the pellicle layer, weak physicochemical forces are generated. Within a short time, these weak physicochemical interactions may become irreversible due to adhesins on the microbial cell surfaces, which are involved in specific interactions with complementary receptors [van der Mei et al., 2008]. Thus, a key event in biofilm formation is the initial adhesion of bacteria to matching host ligands.

The aim of this study was to investigate the effect of pellicle modification by casein, mucin and a casein-mucin mixture as a potential alternative to prevent dental erosion and adhesion of early bacterial colonizers Streptococcus gordonii, Streptococcus oralis and Actinomyces odontolyticus.

\section{Materials and Methods}

The bacteria used for this study were: S. gordonii ATCC 10558, S. oralis ATCC 35037 and A. odontolyticus ATCC 17982. The strains were maintained on tryptic soy agar (Oxoid, Basingstoke, $\mathrm{UK}$ ) with $5 \%$ sheep blood. They were always passaged $16 \mathrm{~h}$ before the experiment.

\section{Saliva Collection}

Whole saliva was collected from healthy volunteers by paraffin stimulation and pooled. Saliva collection was approved by the Ethics Committee of the University of Bern. To remove debris, saliva was centrifuged for $20 \mathrm{~min}$ at $4{ }^{\circ} \mathrm{C}$ and $4,000 \mathrm{~g}$. The supernatant was sterilized using UV radiation for $30 \mathrm{~min}$. The processed, sterile saliva sample (tested by cultivation) was then stored at $-80^{\circ} \mathrm{C}$; aliquots of saliva were defrosted immediately before the experiment.

\section{Preparation of Human Tooth Specimens}

After patients had given informed consent for the use of their extracted teeth for research purposes (in accordance with the regulations of the Ethics Committee of the University of Bern), cavityfree human premolars were selected and viewed (magnification $\times 25$ ) under a stereomicroscope (Leica Zoom 2000; Leica Microsystems, Buffalo, N.Y., USA) to choose specimens with a sound undamaged surface. Tooth crowns were separated from the roots using an IsoMet ${ }^{\circledR}$ Low Speed Saw (Buehler, Düsseldorf, Germany). The buccal sites were then divided into small cubical slabs and polished on a Knuth-Rotor polishing machine with carbide paper (grain size: 30, 18 and $6 \mu \mathrm{m}$ ) under water cooling. The cubes had a size of about $2 \times 2 \times 0.75 \mathrm{~mm}$ and consisted of enamel only (checked by stereomicroscopy).

Samples were stored in a mineral solution $\left(1.5 \mathrm{mmol} / \mathrm{l} \mathrm{CaCl}_{2}\right.$, $1.0 \mathrm{mmol} / \mathrm{K} \mathrm{KH}_{2} \mathrm{PO}_{4}, 50 \mathrm{mmol} / \mathrm{l} \mathrm{NaCl}, \mathrm{pH}$ 7.0). Prior to the experimental procedures, the samples were disinfected in ethanol (70\%) for $1 \mathrm{~h}$ and washed in sterile deionized water for a further $1 \mathrm{~h}$.

\section{Calculation of Specimen Surface Areas}

The determination of the surface area was performed using a light microscope (Leica M 420). Every side of each tooth specimen was manually outlined using Software IM500, and the surface was measured taking into account the corresponding magnification factor of the microscope. The total surface area was calculated as the sum of the areas of all the faces.

\section{In vitro Bacterial Adhesion Assay}

For each bacterial strain, enamel specimens were randomly selected and divided into eight groups ( $\mathrm{n}=20$ per group): (1) native enamel; (2) pellicle layer; (3) enamel incubated in $0.5 \%$ aqueous (aq.) casein (from bovine milk; Merck for analysis); (4) enamel incubated with $0.27 \%$ aq. mucin (gastric mucin from pig; Merck for analysis); (5) enamel incubated in $0.5 \%$ aq. casein- $0.27 \%$ aq. mucin; (6) pellicle incubated in $0.5 \%$ aq. casein; (7) pellicle incubated in $0.27 \%$ aq. mucin, and (8) pellicle incubated in $0.5 \%$ aq. casein- $0.27 \%$ aq. mucin. The chosen concentrations are based on the results of previous studies and provide buffering potential similar to human salivary proteins [Cheaib and Lussi, 2011]. To prepare protein and protein-modified pellicle coatings, enamel was incubated in the corresponding aq. solution of the proteins (casein, mucin and casein-mucin mixture) for $2 \mathrm{~h}$, or in sterile human saliva for $2 \mathrm{~h}$ followed by protein aq. solution for $2 \mathrm{~h}$ for pellicle coated by protein groups (or left in saliva for $2 \mathrm{~h}$ ), at room temperature under sterile conditions immediately before starting the experiments. Samples were then contaminated with bacterial suspension $\left(\mathrm{OD}_{600}=1.05\right.$; equivalent to $\left.10^{8} \mathrm{bacteria} / \mathrm{ml}\right)$ for $30 \mathrm{~min}$ or $2 \mathrm{~h}$ in Dulbecco's modified Eagle's medium (DMEM; Gibco, Invitrogen) under slow-motion irrigation before being carefully dipped in DMEM to eliminate nonadhering bacteria. Samples were soaked in $\mathrm{NaCl} 0.9 \%$, and bound bacteria were dispersed by sonication for $30 \mathrm{~s}$. The samples were vortexed for a further $30 \mathrm{~s}$, serially diluted and spread over a tryptic soy agar plate. The media were incubated at $37^{\circ} \mathrm{C}$ with $5 \%$ carbon dioxide for $48 \mathrm{~h}$ and bacterial colonies were then counted using an aCOLyte SuperCount 
colony counter (Synbiosis, UK). The number of bacteria was measured as colony-forming units (CFU). Results are expressed as $\log _{10}$ CFU per square millimeter. Two specimens per coating and time were independently included in one run, i.e. at least 10 runs were conducted per bacterial strain.

\section{Statistical Analysis}

All statistical analysis was performed with R, version 2.15.1, using the extension package exactRank tests. A global significance level of $\alpha=0.05$ had to be achieved.

Since the data did not fulfill the assumptions of a parametric ANOVA (heteroskedastic groups, i.e. unequal variances), a nonparametric approach known as ART (aligned rank transformation) [Higgins, 2004] was applied. Comparisons between different groups were made using the Kruskal-Wallis test.

\section{Results}

Eight groups at two different sampling times per bacterial strain ( $n=20$ /group) were compared in the experiment. Slabs of native enamel, enamel slabs coated with a pellicle layer, casein, mucin and casein-mucin mixture, and enamel slabs coated first with a pellicle layer followed by casein, mucin and casein-mucin mixture were prepared. All test groups were incubated for $30 \mathrm{~min}$ or $2 \mathrm{~h}$ with S. gordonii ATCC 10558, S. oralis ATCC 35037 or A. odontolyticus ATCC 17982.

\section{Bacterial Adhesion to Native Enamel and}

Pellicle-Covered Enamel with Different Coatings

$S$. gordonii. The adhesion rate of S. gordonii ATCC 10558 was significantly higher to pellicle-coated enamel than to native enamel after incubation for $30 \mathrm{~min}$ and $2 \mathrm{~h}$ $(\mathrm{p}=0.017 ; \mathrm{p}<0.001)$. After $30 \mathrm{~min}$, coating with casein and casein-mucin decreased the adhesion of $S$. gordonii ( $\mathrm{p}=0.006 ; \mathrm{p}=0.005)$ compared to native enamel, and after $2 \mathrm{~h}$ there was still less adhesion after casein-mucin coating ( $\mathrm{p}=0.040$; all: $\mathrm{p}=0.010, \mathrm{p}=0.155)$. When comparing pellicle-covered enamel, all modifications significantly decreased the adhesion of $S$. gordonii after $30 \mathrm{~min}$ (casein $\mathrm{p}=0.002$, mucin and casein-mucin both $\mathrm{p}<$ 0.001 ) and after $2 \mathrm{~h}$ the lowest rate was found after caseinmucin with a median reduction of up to $0.43 \log _{10} \mathrm{CFU}$ (or 63\%, $\mathrm{p}=0.001$; all: $\mathrm{p}<0.001, \mathrm{p}=0.003$ ). However, counts were higher when comparing modified pellicle with native enamel coated with the respective proteins [casein after $30 \mathrm{~min}$ and $2 \mathrm{~h}(\mathrm{p}<0.001 ; \mathrm{p}=0.006)$, mucin and casein-mucin after $2 \mathrm{~h}(\mathrm{p}=0.011 ; \mathrm{p}=0.009$; fig. 1$)]$.

S. oralis. The adhesion rate of S. oralis ATCC 35037 was significantly higher in pellicle-coated enamel than in native enamel after incubation for $30 \mathrm{~min}$ and $2 \mathrm{~h}(\mathrm{p}<$

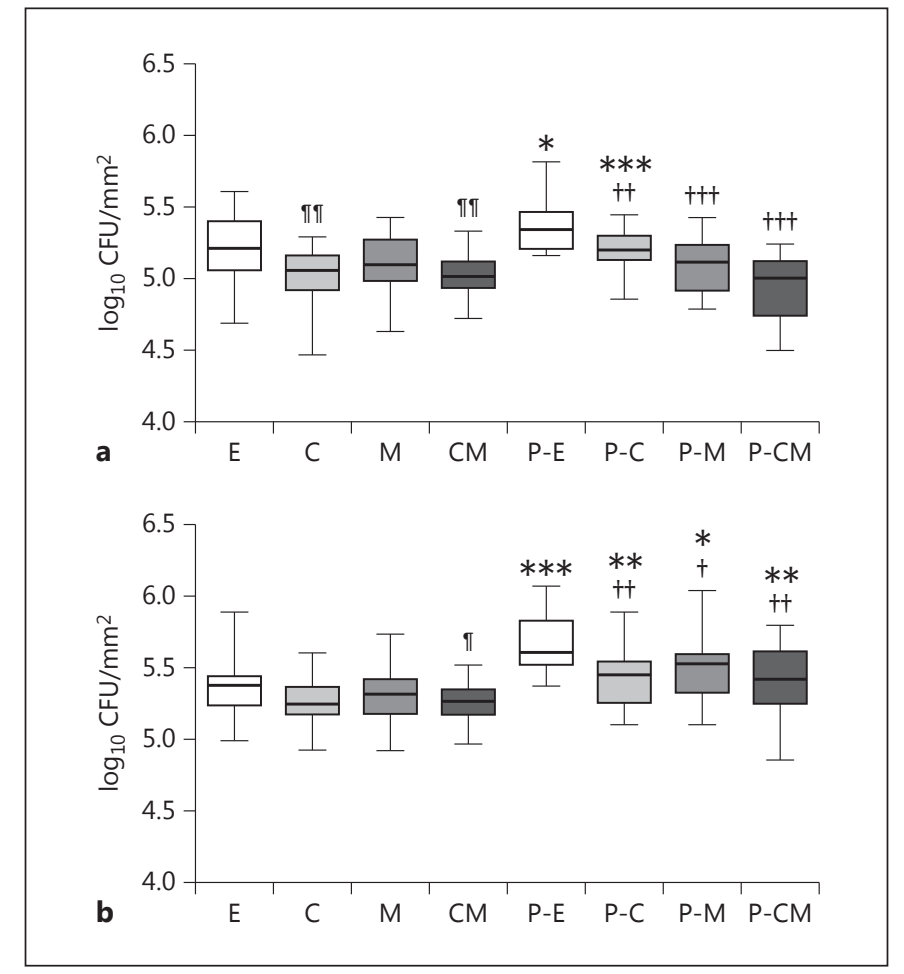

Fig. 1. Number (minimum, maximum, quartiles) of $S$. gordonii ATCC 10558 adhering to different surfaces: native enamel (E), pellicle-covered enamel (P-E), enamel coated with casein (C), enamel coated with mucin $(M)$, enamel coated with casein-mucin $(C M)$, and enamel covered with pellicle modified by casein (P-C), mucin $(\mathrm{P}-\mathrm{M})$ and casein and mucin (P-CM) after $30 \mathrm{~min}(\mathbf{a})$ and $2 \mathrm{~h} \mathrm{(b)}$ of incubation. ${ }^{*} \mathrm{p}<0.05 ;{ }^{* *} \mathrm{p}<0.01 ;{ }^{* * *} \mathrm{p}<0.001$, vs. the same coating without pellicle; $\pi \mathrm{p}<0.05$; ${ }^{\pi} \mathrm{p}<0.01$, vs. enamel, and ${ }^{\dagger} \mathrm{p}<0.05 ;{ }^{\dagger \dagger} \mathrm{p}<0.01 ;{ }^{\dagger \dagger} \mathrm{p}<0.001$, vs. pellicle-covered enamel.

$0.001 ; \mathrm{p}=0.001)$. After $30 \mathrm{~min}$ and $2 \mathrm{~h}$, coating with casein $(\mathrm{p}=0.002 ; \mathrm{p}=0.013)$, mucin $(\mathrm{p}=0.034 ; \mathrm{p}=0.002)$ and with casein-mucin $(\mathrm{p}<0.001 ; \mathrm{p}=0.006)$ decreased the adhesion of $S$. oralis compared to native enamel (all: $\mathrm{p}=0.001, \mathrm{p}=0.009)$. With regard to pellicle-covered enamel, mucin and casein-mucin modifications significantly decreased the adhesion of $S$. oralis after $30 \mathrm{~min}$ $(\mathrm{p}=0.038 ; \mathrm{p}<0.001)$; the difference was still significant for casein-mucin after $2 \mathrm{~h}$ ( $\mathrm{p}=0.020$; all: $\mathrm{p}=0.001, \mathrm{p}=$ 0.057 ). All bacterial counts were higher when comparing modified pellicle with native enamel coated with the respective proteins (each $\mathrm{p}<0.001$ ) after $30 \mathrm{~min}$ and $2 \mathrm{~h}$ of incubation (fig. 2).

A. odontolyticus. The adhesion rate of A. odontolyticus ATCC 17982 was significantly higher in pellicle-coated enamel than in native enamel after $30 \mathrm{~min}$ and $2 \mathrm{~h}$ of incubation (both $\mathrm{p}<0.001$ ). Coating with casein, mucin or 


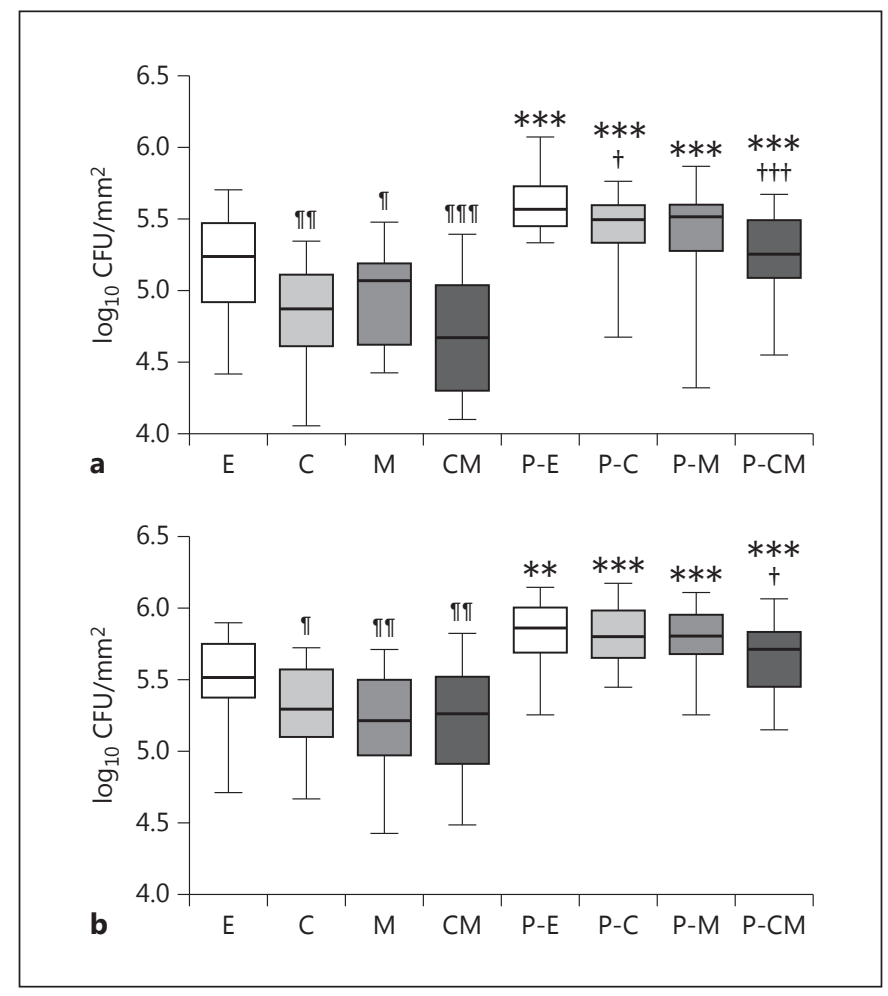

Fig. 2. Number (minimum, maximum, quartiles) of S. oralis ATCC 35037 adhering to different surfaces after $30 \mathrm{~min}(\mathbf{a})$ and $2 \mathrm{~h} \mathrm{(b)} \mathrm{of}$ incubation. ${ }^{\pi \pi T} p<0.001$ vs. enamel. See legend to figure 1 for $a b-$ breviations and significance values.

casein-mucin did not change the adhesion of $A$. odontolyticus to native enamel (all: $\mathrm{p}=0.348, \mathrm{p}=0.247$ ). In the case of pellicle-covered enamel, modifications with casein significantly decreased the counts of $A$. odontolyticus after $30 \mathrm{~min}(\mathrm{p}=0.009)$ and modifications with mucin after $2 \mathrm{~h}(\mathrm{p}=0.004)$. The casein-mucin mixture inhibited bacterial adhesion after $30 \min (\mathrm{p}=0.003)$ and $2 \mathrm{~h}(\mathrm{p}<$ 0.001 ; all: $p=0.011, p=0.001$ ). Counts were higher when comparing modified pellicle with native enamel coated with the proteins: casein after $2 \mathrm{~h}(\mathrm{p}=0.020)$, mucin after 30 min and $2 \mathrm{~h}(\mathrm{p}<0.001 ; \mathrm{p}=0.006)$ and casein-mucin after $30 \mathrm{~min}$ ( $\mathrm{p}=0.015$; fig. 3$)$.

\section{Comparison between Adhesion of Bacterial Strains after 30 min and $2 \mathrm{~h}$ of Incubation}

After $2 \mathrm{~h}$, the counts of adherent bacteria were always higher than after $30 \mathrm{~min}$; the difference ranged from 0.14 $\log _{10} \mathrm{CFU} / \mathrm{mm}^{2}$ (S. oralis ATCC 35037 coating with casein) to $0.59 \log _{10} \mathrm{CFU} / \mathrm{mm}^{2}$ (S. oralis ATCC 35037 coating with casein-mucin).

Pellicle Modification and Adhesion of Early Colonizers

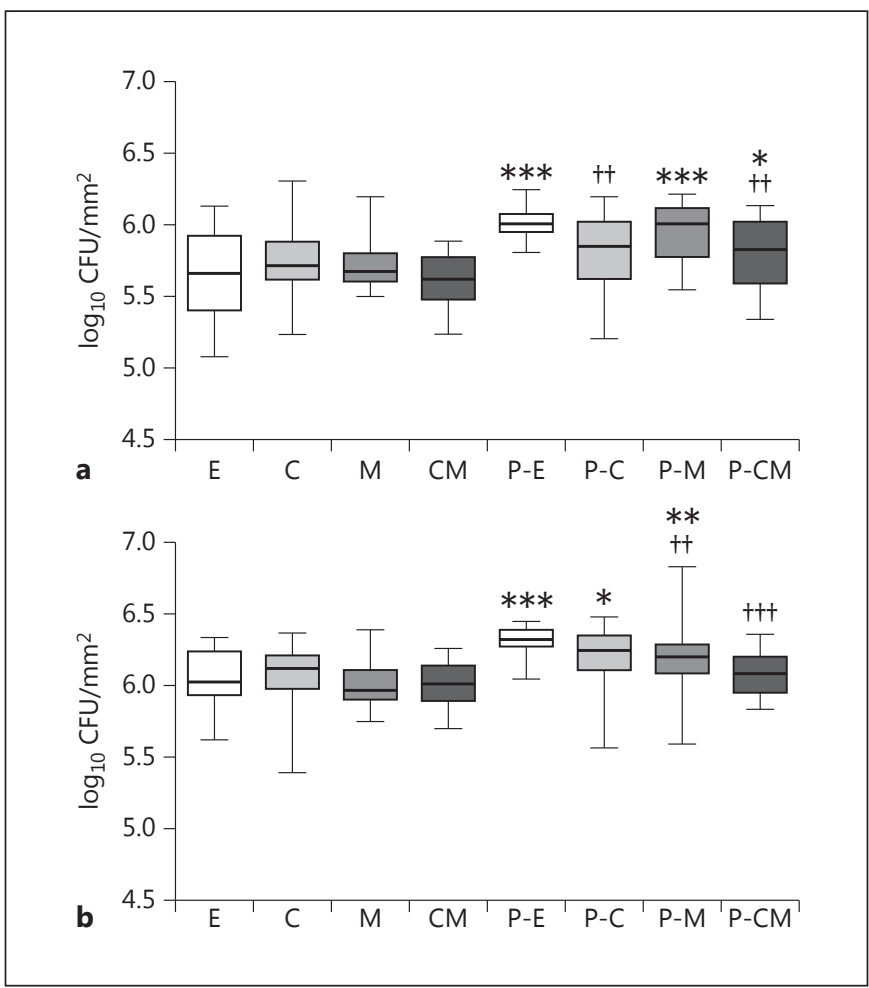

Fig. 3. Number (minimum, maximum, quartiles) of adhered $A$. odontolyticus ATCC 17982 to different surfaces after $30 \mathrm{~min}$ (a) and $2 \mathrm{~h}$ (b) of incubation. See legend to figure 1 for abbreviations and significance values.

The rate of bacterial adhesion to native and pelliclecoated enamel with and without modifications was always the highest for A. odontolyticus ATCC 17982. The rate was always significantly different $(\mathrm{p}<0.001)$ from those of S. oralis ATCC 35037 and S. gordonii ATCC 10558, both after $30 \mathrm{~min}$ and after $2 \mathrm{~h}$. Furthermore, $S$. oralis adhered in greater numbers than $S$. gordonii to native enamel at $2 \mathrm{~h}(\mathrm{p}=0.007)$, and to pellicle-covered enamel with and without modifications after $30 \mathrm{~min}$ (without modifications $\mathrm{p}=0.001$; casein and mucin both $\mathrm{p}<0.001$, casein-mucin $\mathrm{p}<0.003$ ) and after $2 \mathrm{~h}$ (without modifications $\mathrm{p}=0.026$; casein $\mathrm{p}<0.001$; mucin $\mathrm{p}=$ 0.001 , casein-mucin $\mathrm{p}<0.006)$. For native enamel coated with casein-mucin, after $30 \mathrm{~min}$, S. gordonii adhered in greater numbers than $S$. oralis $(\mathrm{p}=0.007)$. There was no difference between the adherence of the two streptococcal strains on native enamel after $30 \mathrm{~min}$, native enamel coated with casein and mucin at either time and native enamel coated with casein-mucin after $2 \mathrm{~h}$. 


\section{Discussion}

We studied the effects of pellicle modification by casein, mucin or a mixture of both on biofilm formation on human enamel. Our previous study showed that the mixture of casein and mucin increased the original ability of pellicle to protect against dental erosion [Cheaib and Lussi, 2011].

Microbial adhesion on tooth surfaces is always preceded by the adsorption of a salivary pellicle [Lendenmann et al., 2000; Hannig and Joiner, 2006]. After adhering, the early colonizers such as Actinomyces spp., S. oralis, Streptococcus mitis, or S. gordonii influence the formation and the composition of the mature biofilm [Kolenbrander, 2000]. Thus, they provide optimal conditions and attachment substrates for the secondary colonizers, i.e. Streptococcus mutans, Fusobacterium nucleatum or Veillonella spp. In this study, S. gordonii ATCC 10558, S. oralis ATCC 35037 and A. odontolyticus ATCC 17982 were used for evaluating early biofilm formation on the protein-modified enamel and protein-modified salivary pellicle. The number of adherent bacteria was higher in the pellicle-coated enamel group than in the native enamel group after 30 and 120 min of incubation. This could be explained by nonspecific and specific interactions which operate together on the pellicle layer leading to a stronger adhesion of $S$. gordonii ATCC 10558, S. oralis ATCC 35037 and A. odontolyticus ATCC 17982 to the pellicle surface. This is in agreement with our previous study [Mai et al., 2014] showing that pellicle promotes more bacterial adhesion than human enamel.

The primary interactions of bacteria with the tooth surface can result from diffusion, sedimentation, liquid flow or from active movement of the bacteria. Interactions between the surface and the bacteria include electrostatic, hydrophobic and van der Waals forces, and lead to firm nonspecific but reversible adhesion of the bacteria to the pellicle [Kolenbrander, 2000]. The irreversible attachment of bacterial cells to the tooth involves specific, stereochemical interactions between bacterial adhesins and complementary receptors in the acquired pellicle. Furthermore, specific interactions strengthen moreover more extended periods of time than nonspecific ones [van der Mei et al., 2008].

The number of bacteria adherent to pellicle and protein-coated pellicle was higher for A. odontolyticus ATCC 17982 than S. gordonii ATCC 10558 and S. oralis ATCC 35037 after both $30 \mathrm{~min}$ and $2 \mathrm{~h}$ of incubation. This could be explained by stronger nonspecific and specific interactions with A. odontolyticus ATCC 17982 than for the two other strains. Actinomyces spp. have two distinct types of fimbriae: type 1 fimbriae mediate adherence to prolinerich proteins and to statherin, whereas type 2 fimbriae are involved in the adherence of bacterial cells to already attached bacteria [Hallberg et al., 1998]. A. odontolyticus expresses a sialic acid-binding specificity potentially related to type 2 fimbriae [Drobni et al., 2006]. This specific interaction with the protein layer via fimbriae may result in stronger binding sites. Adhesins on S. gordonii can bind to a-amylase [Rogers et al., 2001]. S. gordonii and S. oralis express LPXTG-linked adhesins which bind to saliva-coated surfaces [Davies et al., 2009; Dorkhan et al., 2012]. The 30-min and 2-hour incubation times in this study were chosen to acquire first-hand knowledge about nonspecific and specific interactions of bacteria with protein-modified enamel and pellicle.

For S. gordonii ATCC 10558, smaller numbers of bacteria adhered to pellicle modified by casein, mucin or a mixture of both, or to enamel modified by proteins, than to nonmodified pellicle. The difference was statistically significant at the two incubation times. Also, for A. odontolyticus ATCC 17982, the number of adherent bacteria was lower in casein-coated pellicle after $30 \mathrm{~min}$ of incubation and in mucin-coated pellicle after $2 \mathrm{~h}$ of incubation compared to the pellicle layer. For S. oralis ATCC 35037, incubation of enamel in saliva followed by protein treatment resulted in lower counts in the casein-mucin-coated pellicle group than in the enamel group covered with pellicle only.

Nonspecific interactions are mainly altered upon addition of casein to the pellicle layer, as the effect had already occurred at $30 \mathrm{~min}$. However, in the case of A. odontolyticus ATCC 17982, specific interactions may be affected upon addition of mucin. The modification of pellicle by the casein-mucin mixture resulted in lower numbers of all the bacteria tested than counted for pellicle at the two incubation times. Casein forms micelle-like structures on the pellicle [Cheaib and Lussi, 2011]. The addition of casein promoted adsorption of mucin, and it is known that mucin interacts weakly with the pellicle layer on salivary pellicle in vitro [Cheaib and Lussi, 2011]. Therefore, the formation of a protein complex between casein and mucin, and its interaction with pellicle, could explain a better shielding barrier between the pellicle layer and oral bacterial cells.

We studied adhesion of initial colonizers to modified pellicle. Independently of the used strain, application of pellicle increased bacterial counts by $0.13-0.34 \log _{10}$ $\mathrm{CFU} / \mathrm{mm}^{2}$ and modification by $0.27 \%$ mucin $-0.5 \%$ casein reduced bacterial adhesion up to $0.33 \log _{10} \mathrm{CFU} /$ $\mathrm{mm}^{2}$. This suggests a nonselective effect of $0.27 \% \mathrm{mu}-$ 
cin- $0.5 \%$ casein resulting in a slight inhibition of bacterial adhesion. A disturbance in bacterial homoeostasis might be excluded. Bacterial homoeostasis in the oral cavity includes the integrity of host defense and the consumption of sugars [Marsh, 2006]. Pulsing of a microbial community with glucose in uncontrolled $\mathrm{pH}$ conditions led to a decrease in acid-sensitive microorganisms such as S. gordonii and S. oralis, favoring acidogenic bacteria, e.g. S. mutans [Bradshaw and Marsh, 1998]. Sequence analysis of severe caries confirmed a decrease in S. gordonii, while S. mutans increased and Actinomyces sp. remained unchanged [Gross et al., 2010]. Casein inhibits the adherence of cariogenic bacteria to saliva-coated surfaces. Sodium caseinate, casein phosphopeptide and glycol-macropeptide inhibited adherence of oral streptococci to saliva-coated hydroxyapatite beads. Anticariogenicity of these proteins and peptides was accomplished by selectively inhibiting adhesion of streptococci to the teeth; the microbial composition of dental plaques was modulated to favor establishment of less cariogenic species, such as oral Actinomyces spp. [Neeser et al., 1994]. Milk and individual caseins ( $\alpha$-, $\beta$ - and $\kappa$-caseins) were studied to determine adherence of $S$. mutans to saliva-coated hydroxyapatite discs. Milk inhibited in vitro adherence of S. mutans GS-5 [Vacca-Smith et al., 1994]. Individual caseins were also examined. No effect on streptococcal adherence was observed when $\alpha$ - or $\beta$-casein was incubated with hydroxyapatite beads. However, $\kappa$-casein inhibited adherence of $S$. mutans GS-5. Inhibitory properties were attributed to a $40-\mathrm{kDa}$ glycoprotein [Vacca-Smith et al., 1994]. It has also been reported that $\alpha-, \beta$ - and $\kappa$-caseins of bovine origin inhibit adhesion of $S$. mutans to saliva-coated hydroxyapatite [Malkoski et al., 2001]. Another study, however, found clear inhibition of adhesion of $S$. mutans strains to saliva-coated hydroxyapatite by the C-terminal fraction of $\beta$-casein [Danielsson Niemi et al., 2009].

In a study in rats, micellar casein was shown to prevent oral colonization by Streptococcus sobrinus and to promote colonization by Actinomyces viscosus. Sodium caseinate was not as effective as micellar casein at inhibiting streptococcal colonization [Guggenheim et al., 1999].

Our adhesion model used sterilized human saliva to provide a close representation of the natural growth conditions. It has been suggested that bacterial attachment in the mouth is sensitive to the ionic strength of saliva. The ionic strength used in this study was $15 \mathrm{mmol} / \mathrm{l}$ for mucin and $11 \mathrm{mmol} / \mathrm{l}$ for casein, which is in line with the strengths used in previous studies [Mai et al., 2014]. The present in vitro study has some limitations because it investigated only the simple adhesion of bacterial strains without considering the influence of other strains. To have standardized conditions, pooled saliva from healthy subjects was used. Saliva from healthy subjects and patients with dental erosion do not differ in the total protein amount [Bardow et al., 2014; Carpenter et al., 2014], but the content of calcium and proteins is reduced in newly formed acquired pellicle on enamel in dental erosion [Carpenter et al., 2014].

Recently, we have shown that pellicle formed with saliva containing a mixture of $0.27 \%$ mucin and $0.5 \%$ casein clearly inhibits loss of microhardness of enamel already after two incubation cycles of $2 \mathrm{~h}$ when being exposed to a $0.65 \%$ citric acid solution [Cheaib and Lussi, 2011]. This modification of the pellicle did not only reduce erosion of enamel [Cheaib and Lussi, 2011] but also slightly reduced bacterial adherence compared to untreated human pellicle. This may be of practical significance in the prevention of caries and erosion, as on the one hand bacterial homoeostasis might not be seriously affected and on the other hand both erosion and caries are widespread around the world. More extensive investigations are required to understand the interaction of a complex oral bacterial community including cariogenic bacteria with the $0.27 \%$ mucin- $0.5 \%$ casein mixture as a potential additive to soft drinks in preventing dental erosion.

\section{Acknowledgments}

The study was funded by the participating institutions. The authors would like to thank M. Weibel (University of Bern) for technical assistance. The statistical support by G. Fischer and Prof. J. Häusler, Institute of Mathematical Statistics, University of Bern, is highly appreciated.

\section{Author Contributions}

All authors (Z. Cheaib, E. Rakmathulina, A. Lussi and S. Eick) conceived and designed the study, analyzed the data and wrote the paper. Z. Cheaib performed the experiments.

\section{Disclosure Statement}

The authors have no conflicts of interest to declare. 


\section{References}

Barbour ME, Shellis RP, Parker DM, Allen GC, Addy M: Inhibition of hydroxyapatite dissolution by whole casein: the effects of $\mathrm{pH}$, protein concentration, calcium, and ionic strength. Eur J Oral Sci 2008;116:473-478.

Bardow A, Lykkeaa J, Qvist V, Ekstrand K, Twetman S, Fiehn NE: Saliva composition in three selected groups with normal stimulated salivary flow rates, but yet major differences in caries experience and dental erosion. Acta Odontol Scand 2014;72:466-473.

Bradshaw DJ, Lynch RJ: Diet and the microbial aetiology of dental caries: new paradigms. Int Dent J 2013;63(suppl 2):64-72.

Bradshaw DJ, Marsh PD: Analysis of pH-driven disruption of oral microbial communities in vitro. Caries Res 1998;32:456-462.

Carpenter G, Cotroneo E, Moazzez R, Rojas-Serrano $\mathrm{M}$, Donaldson N, Austin R, Zaidel L, Bartlett D, Proctor G: Composition of enamel pellicle from dental erosion patients. Caries Res 2014;48:361-367.

Cheaib Z, Lussi A: Impact of acquired enamel pellicle modification on initial dental erosion. Caries Res 2011;45:107-112.

Danielsson Niemi L, Hernell O, Johansson I: Human milk compounds inhibiting adhesion of mutans streptococci to host ligand-coated hydroxyapatite in vitro. Caries Res 2009;43:171178.

Davies JR, Svensater G, Herzberg MC: Identification of novel LPXTG-linked surface proteins from Streptococcus gordonii. Microbiology 2009;155:1977-1988.

Dorkhan M, Chavez de Paz LE, Skepo M, Svensater G, Davies JR: Effects of saliva or serum coating on adherence of Streptococcus oralis strains to titanium. Microbiology 2012;158 390-397.

Drobni M, Hallberg K, Ohman U, Birve A, Persson K, Johansson I, Stromberg N: Sequence analyses of fimbriae subunit FimA proteins on Actinomyces naeslundii genospecies 1 and 2 and Actinomyces odontolyticus with variant carbohydrate binding specificities. BMC Microbiol 2006;6:43.

Gross EL, Leys EJ, Gasparovich SR, Firestone ND, Schwartzbaum JA, Janies DA, Asnani K, Griffen AL: Bacterial 16S sequence analysis of severe caries in young permanent teeth. J Clin Microbiol 2010;48:4121-4128.
Guggenheim B, Schmid R, Aeschlimann JM, Berrocal R, Neeser JR: Powdered milk micellar casein prevents oral colonization by Streptococcus sobrinus and dental caries in rats: a basis for the caries-protective effect of dairy products. Caries Res 1999;33:446-454.

Hallberg K, Holm C, Ohman U, Stromberg N: Actinomyces naeslundii displays variant fimP and fimA fimbrial subunit genes corresponding to different types of acidic proline-rich protein and beta-linked galactosamine binding specificity. Infect Immun 1998;66:44034410 .

Hannig M, Joiner A: The structure, function and properties of the acquired pellicle. Monogr Oral Sci 2006; 19:29-64.

Hemingway CA, Shellis RP, Parker DM, Addy M, Barbour ME: Inhibition of hydroxyapatite dissolution by ovalbumin as a function of $\mathrm{pH}$, calcium concentration, protein concentration and acid type. Caries Res 2008;42:348-353.

Higgins JJ: Introduction to Modern Nonparametric Statistics. Pacific Grove, Duxbury, 2004.

Jaeggi T, Lussi A: Prevalence, incidence and distribution of erosion. Monogr Oral Sci 2014; 25:55-73.

Kassebaum NJ, Bernabe E, Dahiya M, Bhandari B, Murray CJ, Marcenes W: Global burden of untreated caries: a systematic review and metaregression. J Dent Res 2015;94:650-658.

Kolenbrander PE: Oral microbial communities: biofilms, interactions, and genetic systems. Annu Rev Microbiol 2000;54:413-437.

Kutsch VK, Young DA: New directions in the etiology of dental caries disease. J Calif Dent Assoc 2011;39:716-721.

Lendenmann U, Grogan J, Oppenheim FG: Saliva and dental pellicle - a review. Adv Dent Res 2000; 14:22-28.

Li J, Helmerhorst EJ, Leone CW, Troxler RF, Yaskell T, Haffajee AD, Socransky SS, Oppenheim FG: Identification of early microbial colonizers in human dental biofilm. J Appl Microbiol 2004;97:1311-1318.

Lussi A, Jaeggi T, Jaeggi-Scharer S: Prediction of the erosive potential of some beverages. Caries Res 1995;29:349-354.

Lussi A, Megert B, Shellis RP, Wang X: Analysis of the erosive effect of different dietary substances and medications. Br J Nutr 2012;107: $252-262$.
Mai T, Rakhmatullina E, Bleek K, Boye S, Yuan J, Volkel A, Grawert M, Cheaib Z, Eick S, Gunter C, Lederer A, Lussi A, Taubert A: Poly(ethylene oxide)-b-poly(3-sulfopropyl methacrylate) block copolymers for calcium phosphate mineralization and biofilm inhibition. Biomacromolecules 2014;15:3901-3914.

Malkoski M, Dashper SG, O'Brien-Simpson NM, Talbo GH, Macris M, Cross KJ, Reynolds EC: Kappacin, a novel antibacterial peptide from bovine milk. Antimicrob Agents Chemother 2001;45:2309-2315.

Marsh PD: Dental plaque as a microbial biofilm. Caries Res 2004;38:204-211.

Marsh PD: Dental plaque as a biofilm and a microbial community - implications for health and disease. BMC Oral Health 2006;6(suppl 1):S14.

Neeser JR, Golliard M, Woltz A, Rouvet M, Dillmann ML, Guggenheim B: In vitro modulation of oral bacterial adhesion to saliva-coated hydroxyapatite beads by milk casein derivatives. Oral Microbiol Immunol 1994;9:193201

Rogers JD, Palmer RJ Jr, Kolenbrander PE, Scannapieco FA: Role of Streptococcus gordonii amylase-binding protein $\mathrm{A}$ in adhesion to hydroxyapatite, starch metabolism, and biofilm formation. Infect Immun 2001;69:70467056.

Sovik JB, Skudutyte-Rysstad R, Tveit AB, Sandvik L, Mulic A: Sour sweets and acidic beverage consumption are risk indicators for dental erosion. Caries Res 2015;49:243-250.

Vacca-Smith AM, Van Wuyckhuyse BC, Tabak LA, Bowen WH: The effect of milk and casein proteins on the adherence of Streptococcus mutans to saliva-coated hydroxyapatite. Arch Oral Biol 1994;39:1063-1069.

van der Mei HC, Rustema-Abbing M, de Vries J, Busscher HJ: Bond strengthening in oral bacterial adhesion to salivary conditioning films. Appl Environ Microbiol 2008;74:5511-5515.

White AJ, Gracia LH, Barbour ME: Inhibition of dental erosion by casein and casein-derived proteins. Caries Res 2011;45:13-20.

Wilder-Smith CH, Materna A, Martig L, Lussi A: Gastro-oesophageal reflux is common in oligosymptomatic patients with dental erosion: a pH-impedance and endoscopic study. United European Gastroenterol J 2015;3:174-181. 